\title{
DEBT FINANCING THE CAPITAL REQUIREMENTS OF SOUTh AFrican INFOrMal MARKET Traders
}

\author{
Derek Schraader, Louise Whittaker and Ian McKay \\ Wits Business School, University of the Witwatersrand \\ Accepted November 2009
}

\begin{abstract}
This paper describes a case study that was undertaken to determine whether formal sector personal debt financing might contribute to the funding of South African informal market traders. The case study was conducted at the Natalspruit informal market in Ekhurhuleni, Gauteng. Quantitative questionnaire surveys and a financial diaries project established that market traders in the market have capital requirements large enough to justify the use of formal sector debt financing, can generate sufficient operating profits to pay for formal sector debt financing and would be willing to utilise formal sector debt financing if given the opportunity. However, formal sector debt financing is most relevant to those informal market traders with the skills and motivation to utilise financing effectively and who are willing to inject more formality into their businesses.
\end{abstract}

Keywords: informal markets, informal trading, micro enterprise finance

JEL 017

\section{1}

\section{Introduction}

Unemployment ${ }^{1}$ in South Africa presently stands at 24.5 per cent (Statistics South Africa, 2009) and is one of our most pressing challenges. This high level of unemployment has been caused by the decline in the labour absorption capacity of the formal economy (Ligthelm, 2006) and may be ameliorated by a growing informal sector that, including trade and private household employment, accounts for over 2.5 million jobs (Statistics South Africa, 2008). However, South Africa's informal sector is still small relative to that of other countries, which suggests that much more can be done to stimulate growth in this area (Kingdon \& Knight, 2005), in order to contribute to the relief of unemployment.

Studies in the Khayelitsha/Mitchell's Plain area (Cichello, 2005), in the Natalspruit trading area (Wits Business School and Progressus Social Research, 2006), and in Gauteng (African Response, 2006) all suggest that informal market traders can be stimulated by making it easier for them to access capital to fund their businesses. According to Kauffman (2006), the problem can be generalised to Africa, where the limited access of small and medium enterprises to finance constricts their growth.

One reason why the informal sector lacks funding is the almost non-existent use of formal sector debt financing. The purpose of this research is therefore to determine whether debt financing would be appropriate in funding the capital requirements of informal market traders. The research took the form of a case study conducted in the Natalspruit informal market, which is situated in the Ekhureleni metropolitan area, Gauteng 2 .

Five aspects of the problem are considered: the capital requirements of informal market traders, the minimum loan amounts that formal sector financial institutions are prepared to lend to informal market traders, the operating profits generated by informal market traders, whether the operating profits will cover the formal sector debt financing and whether informal trader would actually be willing to utilise formal sector debt financing. 
Each of these aspects is discussed in the literature review that follows. The methodology used in the case study research is then detailed, and the results presented. A discussion of the case study with respect to each of the five sub-problems leads to conclusions and recommendations.

\section{2}

\section{Literature review}

\subsection{Informal traders}

The literature study revealed that a number of interchangeable terms are used to describe 'informal or street traders' whose trading activity is not always viewed positively by the authorities. According to a report produced by the City of Cape Town, street traders sell goods and services on public property without the necessary business permits, typically in violation of existing zoning codes. They are also characterised by a failure to report on tax liabilities (Ukuhula Business Solutions, 2002).

Informal traders are involved in a wide variety of economic activities including hair cutting, selling of clothes and related items, repairing and making of shoes and selling of leather goods (Hunter \& Skinner, 2003). Despite the overall diversity of the activities only a few types are really common. Ligthelm (2005) reports that almost two in every three informal businesses in Tshwane sell fruit and vegetables, cool drinks, sweets, cigarettes, clothing or cooked food.
These two aspects of informal traders, namely their unofficial nature and the diversity of their activities, need to be born in mind when discussing their capital requirements and the possible use of formal sector finance.

\subsection{Capital requirements of informal traders}

The sheer diversity of informal traders' size, scope, activities and profitability makes it important to segment them when analysing their capital requirements (Lalthapersad-Pillay, 2004). These requirements range from start-up costs, operating costs, trading facilities (e.g. a shelter, tables and chairs, a container, storage facilities etc.), and inventory through to the financing of tools and equipment to deliver services (Ligthelm \& Van Wyk, 2004).

According to the Department of Trade and Industry (2004), the amount of start-up capital required differs according to the type of business. General dealers required between R8 000 and R10 000, spaza shops required between R2 000 and R4 000, and hawkers ${ }^{3}$ required between R1 000 and R2 000 .

The Department of Trade and Industry's findings are supported by Skinner's (2005) research on the start-up capital requirements of informal market traders in the Durban area as shown in Table 1. African Response (2006) produced similar results suggesting that informal market trading businesses require minimum start up amounts of R0-500.

Table 1

Start-up capital requirements in Durban area

\begin{tabular}{|l|r|r|}
\hline \multicolumn{1}{|c|}{ Start-up capital range } & Percentage of workers & \multicolumn{2}{c|}{$\begin{array}{c}\text { Cumulative percentage } \\
\text { of workers }\end{array}$} \\
\hline R0 -500 & 38.4 & 38.4 \\
\hline R501 - R1,000 & 12.0 & 50.4 \\
\hline R1,001 - R5,000 & 30.7 & 81.1 \\
\hline R5,001 - R10,000 & 8.9 & 90.0 \\
\hline$>$ R10,000 & 10.0 & 100.0 \\
\hline
\end{tabular}




\subsection{Formal sector debt financing}

The term 'debt financing' is a broad term referring to borrowing other people's money in order to generate profits (Gitman, 2000). 'Debt financing' includes the loans, credit cards and revolving credit provided by financial institutions such as bank and micro-lenders operating within the ambit of the National Credit Regulator (NCR). By contrast informal sector debt financing institutions do not operate within the ambit of the NCR and include include stokvels, credit associations and informal, groupbased rotating savings associations (Schoombee, 1999).

Although Schreiner (2001) highlights multiple factors worth considering, including term to maturity, average balance, time between instalments, the number of instalments, instalment amount and years of borrowed resources, this research focused on the minimum debts formal sector institutions are prepared to lend and the associated finance costs.

\section{Minimum loan amounts}

The most recent available research on minimum loan amounts, by Bay Research and Consultancy Services (2005) suggests that the minimum amount that various micro-lenders would be prepared to lend varied between R433 and R800.

\section{Finance costs}

Unfortunately, the literature related to the financing costs for the use of debt financing by informal traders is not extensive. What literature does exist points to an environment characterised by exorbitant interest rates (Schoombee, 2004). The National Credit Act (Republic of South Africa, 2005) legislates that interest rates on unsecured or developmental credit may be a maximum of 2.2 times the repo rate plus 20 per cent.

\subsection{Profitability}

The viability of formal sector debt financing is dependent upon the ability of informal market traders to generate sufficient operating profits in order to repay the loan and associated financing costs. Generally, information and literature regarding the profitability of informal market traders is sparse because these businesses keep only limited records (Skinner, 2005). Furthermore, the literature that does exist typically refers to profitability in a very generic manner.

Skinner studied the constraints of growth and employment in Durban between January and April 2005 and concluded that the majority of informal businesses interviewed were profitable. The University of South Africa's Bureau of Market Research estimated informal businesses surveyed in Tshwane were generating monthly net profits of between R1 115 and R13 375 based on a net profit margin of 25 per cent (Ligthelm \& Van Wyk, 2004).

Lathapersad-Pillay's (2004) survey of African female street traders in the Johannesburg CBD revealed that 11 per cent of respondents took home between R60 and R100 per week (R260 and R433 per month), 30 per cent took home between R120 and R200 per week (R520 and R867 per month), 17 per cent took home between R220 and R250 per week (R953 and R1 083 per month) and 52 per cent took home between R300 and R380 per week (R1 300 and R1 647 per month). A similar survey conducted by African Response (2006) yielded lower net profits of R388 per month ${ }^{4}$. The literature suggested that most street traders did generate profits albeit in a wide range.

\subsection{Formal sector debt financing attractiveness}

Formal sector debt financing has a role to play only in funding the capital requirements of informal market traders if they are willing to utilise this form of financing. According to the literature the use of formal sector debt financing by informal market traders is very limited. In the survey conducted by the Wits Business School and Progressus Social Research (2006), only 3 per cent of all respondents stated that they had borrowed money from a bank to finance their business. Most of the informal market traders surveyed had either borrowed money from their families or had accessed their own savings to finance their businesses. These findings were not dissimilar to Skinner (2005) who reported that 
only 3.9 per cent of all respondents had accessed financing from a bank. Most of the respondents surveyed had either used their own savings or borrowed money from relatives or friends.

One of the most frequently cited reasons for the reluctance of informal market traders to apply for formal sector debt financing is the high cost of interest and initiation fees (Skinner, 2005). However, Glackin (2002) contends that these costs include a number of additional components (including non-financial costs) which must also be taken into account as shown in Table 2.

Table 2

Microloan associated costs

\begin{tabular}{|l|l|l|}
\hline \multicolumn{1}{|c|}{ Financial costs } & \multicolumn{1}{c|}{ Transaction costs } & \multicolumn{1}{c|}{ Psychosocial costs } \\
\hline Application fees & Training time & Loss of privacy \\
\hline Training fees & Technical assistance time & Risk aversion \\
\hline Closing costs & Travel time & Stigma \\
\hline Technical assistance fees & Pledged collateral & Frustration \\
\hline Child care & Equity required & \\
\hline Late fees and penalties & Loss of means & \\
\hline Interest & Lost wages & \\
\hline
\end{tabular}

Source: Glackin (2002)

The reluctance of informal market traders to apply for formal sector debt financing may also be attributed to the fact that they lack the required guarantees and that the procedures are too complicated (Skinner, 2005). Glackin (2002) cites a number of other reasons, including perceived discrimination, regulatory and legal concerns, limited or poor credit history, lack of collateral, lack of knowledge about microloan programmes, geographic constraints and mistrust of financial institutions.

\section{3}

\section{Methodology}

The research design took the form of an indepth case study designed to provide a detailed financial profile of traders in the Natalspruit market. In order to address the five different aspects of the research problem, multiple surveys and an in-depth diary project were conducted. Four different questionnaires were used to collect information on the capital requirements of informal market traders, the minimum loan amounts that formal sector financial institutions are prepared to lend and the associated costs and procedures, and the willingness of informal market traders to utilise formal sector debt financing. Financial diaries were used to collect profitability data from 35 purposively selected traders in the market.

Two populations were surveyed: informal market traders of Natalspruit and financial institutions providing loans in South Africa. The Natalspruit trading area is situated in Katlehong in the Ekurhuleni Metropolitan Council and in July 2006 was home to 805 informal market stalls (Wits Business School and Progressus Social Research 2006). All relevant permissions and the traders' consent were obtained before the surveys were administered.

Those financial institutions registered with the National Credit Regulator (NCR) as of 1 January 2007 constituted the second population. The NCR was established as a regulator under the National Credit Act No. 34 of 2005 and is responsible for the regulation of the South African credit industry (Republic of South Africa 2005). 


\subsection{Capital requirements questionnaire}

Ninety-nine traders filled in the Capital Requirements Questionnaire together with the researcher. Each questionnaire took about 20 minutes to complete and each trader was compensated for their time with a payment of R5.

The aim of the questionnaire was to establish the capital requirements of each informal market trader's business in its current state. This was done by asking the trader what amount would be required, and what it would be used for. Observation was also employed to improve the accuracy of the amount estimated.

To ensure that the sample selected for this survey reflected the spread of informal market traders in Natalspruit, a minimum of 30 traders were selected from each of the three main types of business in the area. These included: (1) clothing, bags/luggage, craft goods and telephone/cell phone goods; (2) telephone/cell phone services, hair dressing, car repairs, sewing services and traditional healing; and (3) fruits and vegetables, meat and meat products, cooked food, uncooked snacks, other food, medicinal plants, toiletries and household goods. These business categories had already been identified by the Wits Business School and Progressus Social Research (2006) survey.

\subsection{Loan questionnaire}

The loan questionnaire was administered using a sample from the NCR registered financial institution population. Thirty loan questionnaires were completed by the researcher based on telephonic conversations conducted with call centre agents throughout the course of April 2007. The data collected included minimum loan amount; (2) maximum repayment period in months; and (3) maximum monthly interest. To accommodate for the variability of the loan amounts required, repayments were calculated for loans ranging from R1 000 to R25 000 in increments of R1 000 .

The nine institutions registered with the Banking Association of South Africa that offer microloans were included in the survey. These institutions are Absa Bank Ltd, African Bank Investments Ltd, Capitec Bank Ltd, First
National Bank of SA Ltd, Meeg Bank Ltd, Nedbank Ltd, Standard Bank of SA Ltd and VBS Mutual Bank. These institutions were included as they collectively provide most of the loans offered in South Africa (but not necessarily most of the microloans).

The remaining 21 institutions were randomly selected from those micro-lenders that were registered with the Micro Finance Regulatory Council $^{5}$, (MRFC), were based in Johannesburg and had telephone numbers listed on the MFRC database.

Obtaining the information required was not straightforward. Firstly, many institutions based their minimum loan amount on the salary of the applicant rather than on an absolute number. In this case a minimum loan amount of R500 was recorded. Secondly, the knowledge of different agents within a call centre was inconsistent. Thirdly, it appeared that call centre agents lacked knowledge of minimum loan amounts because they were used to giving information on maximum rather than minimum loans. Fourthly, call centre agents, particularly in the smaller institutions, seemed to be wary of 'people asking too many questions'. Ultimately the information was collected simply by requesting a micro-loan.

\subsection{Profitability and financial diaries project}

A sub-sample of 35 traders was selected for the financial diaries project from the sample of 99 informal market traders who participated in the Capital Requirements Questionnaire. The 35 informal market traders were purposively selected according to their willingness to participate in the Profitability Questionnaire process and their ability to record all the information required. The questionnaires were piloted, appropriately modified and these traders received training a day before the project commencement. Each trader received a special 35 page financial diary, a marking board and a pen.

Each day, participating traders were required to fill in a page recording their incomes and expenses of the day. A ' + ' was used to indicate income and a '-' was used to indicate expenses. Data were collected from the traders every 
second or third day and remedial action was taken to assist the traders and avoid loss of data through poor recording practices.

In certain cases traders who were competent at collecting their data were asked to help other traders who were struggling. Personal relationships were built up with the traders and this appeared to motivate them to collect the required data accurately. In addition, traders were paid a daily incentive of R10 to fill in the forms, which was intended to compensate them for the time invested in doing so.

Another advantage of observing the trader's businesses and building relationships with them was that it enabled an additional check on the validity of the data collected. Having adjusted for data quality problems, the data collected are a good approximation of the profitability of each of the 33 traders. This financial diaries project provides actual trading data for informal market traders, which, to our knowledge, has not been done elsewhere in South Africa. There are some limitations to this method, most pertinently that the traders were not randomly selected - this in order to maximise the rate of successful completion of the diaries. However, the financial diaries provide more accurate and detailed data than the self-reported or assumed profit margin that has hitherto been available. Therefore, although we cannot claim that the data are generalisable to all informal market traders in South Africa, firstly since this is a single case study, and secondly because the traders were not randomly selected, we do consider that this project is an important step towards understanding the profitability of informal market traders in South Africa.

\subsection{Formal sector debt financing attractiveness questionnaire}

A sample size of 30 was chosen for the Formal Sector Debt Financing Attractiveness Questionnaire, which was completed by the researcher together with the respondents. The data collected from the Formal Sector Debt Financing Attractiveness Questionnaire included whether the respondents comply with typical formal sector lending requirements (conditions and documents), current and previous banking and financing activities, the attractiveness of formal sector debt financing, possible preferences for other types of financing and general lending comments and recommendations.

All the quantitative data collected were subjected to descriptive statistical analysis using Number Cruncher Statistical Systems (NCSS) software. Content analysis was performed on the Loan Questionnaires.

\section{4}

Results

\subsection{Capital requirements}

Results for the capital requirements questionnaire are summarised in tables 3 and 4. Mean capital requirements (Table 3 ) for all the categories of traders were R3 735, with a standard deviation of R4 611 and a range of R29 995.

Table 3

Analysis of capital requirements

\begin{tabular}{|l|r|}
\hline Count & 99 \\
\hline Mean & R3 735 \\
\hline Standard deviation & R4 611 \\
\hline Minimum & R45 \\
\hline Maximum & R30000 \\
\hline Range & R29 955 \\
\hline
\end{tabular}




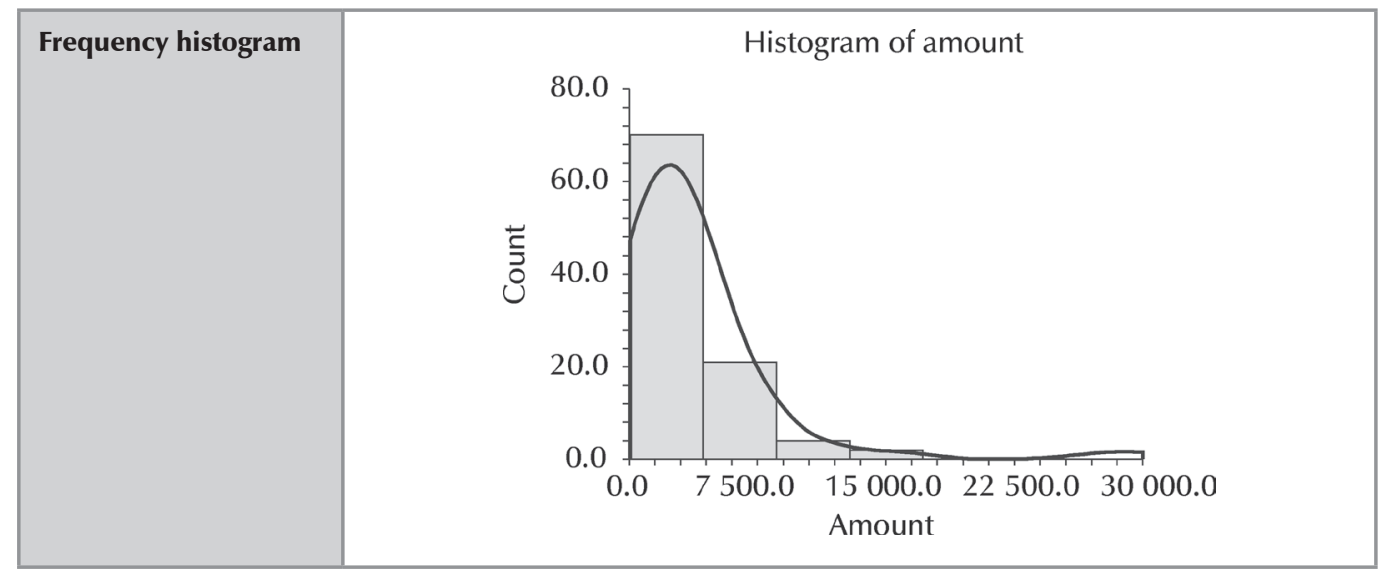

Two traders included their bakkies, which they used to transport goods, in their capital requirements hence the maximum requirements of R30 000 in Table 3.
Capital requirements for the three categories of business were almost identical (Table 4) with category 1 businesses requiring a mean of R3 551, category 2 businesses a mean of R3 710 and category 3 a mean of R3 998.

\section{Table 4}

Analysis of capital requirements based on goods/services sold

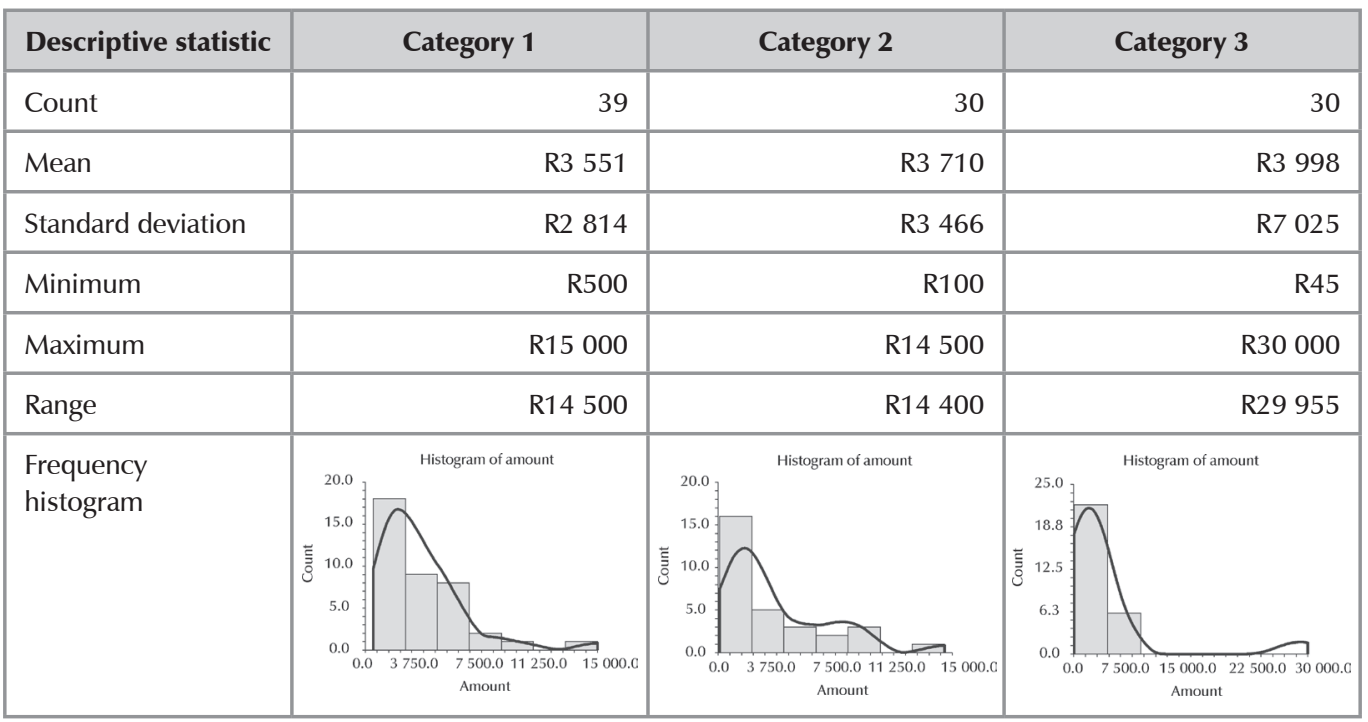

\subsection{Loan minimum amounts}

Data on the minimum amounts that formal sector institutions are prepared to lend are presented in Tables 5 and 6 . The analysis revealed the mean amount was R875, but varied from R50 to R4 000 with a standard deviation of R943 (Table 6). 
Table 5

Analysis of minimum loan amount

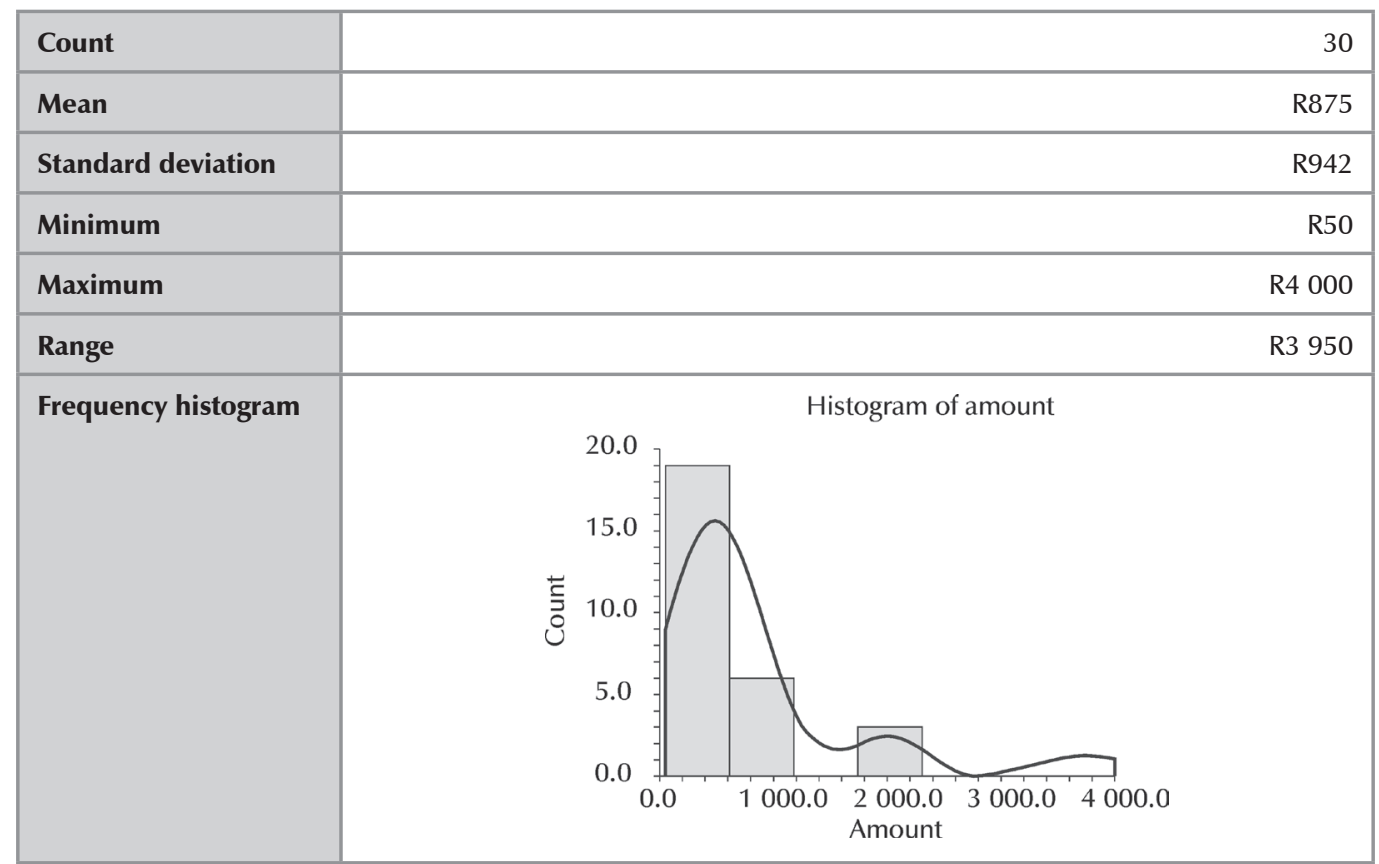

However, much of this variation can be attributed to five institutions whose minimum loan amounts were above R1 000. The comparison of the 'big four' banks with the other 26 institutions provided in Table 6 reveals that the mean minimum loan amount that the big banks are prepared to lend is R2 125 , considerably more than that of the other organisations.

Table 6

Segmented analysis of minimum loan amounts

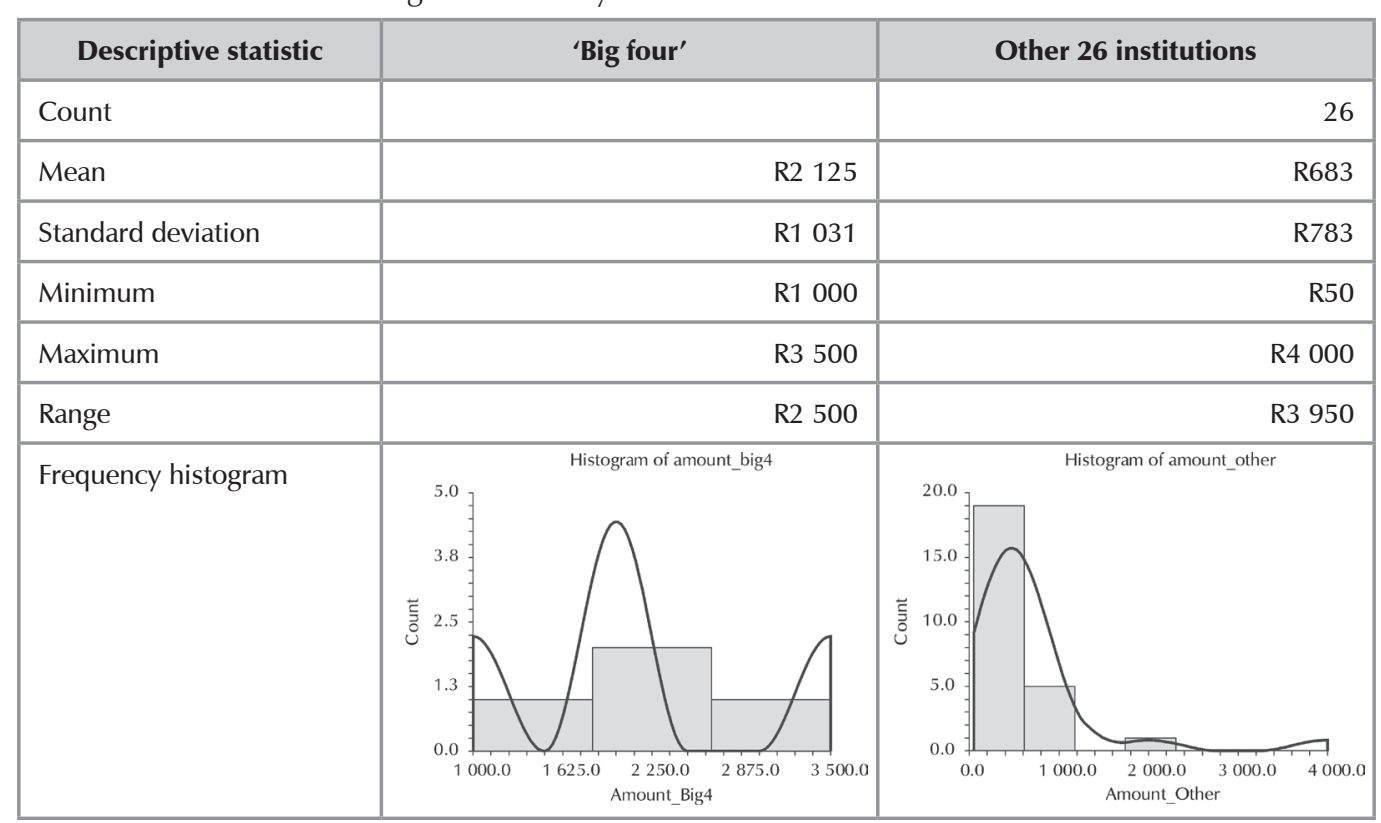




\subsection{Finance costs}

Table 7 summarises the maximum finance costs on micro-loans ranging between R1 000 R10 000 in increments of R1 000. The following should be taken into account when analysing the table. A maximum repayment period of six months, instead of the eight months recorded, was used in calculations to accommodate the requirements of the National Credit Act (Republic of South Africa, 2005) which was implemented after this study was commenced.

Additionally, the maximum monthly interest rate chargeable in terms of the National Credit Act was used for calculation purposes instead of the average maximum monthly interest rate charged at the time of data collection. Therefore, an interest rate of 5 per cent per month instead of 24 per cent per month was used. It must be borne in mind that the maximum repayment period in months and the maximum monthly interest rate were merely indicative and could change based on the merits of each individual borrower.

Also, to comply with the National Credit Act an additional maximum initiation fee and maximum service fee were added to the previously mentioned range of loan amounts. The maximum initiation fee used was that stipulated for short term credit transactions: R150 per credit agreement, plus 10 per cent of the amount of the agreement in excess of R 1000 (but never to exceed R1 000). This fee was equally allocated across each of the six months (maximum repayment period). The maximum service fee used was R50 per month.

Table 7

Finances costs for loans ranging between R1 000 and R10 000

\begin{tabular}{|c|c|c|c|c|}
\hline $\begin{array}{c}\text { Loan amount } \\
(\mathbf{R})\end{array}$ & $\begin{array}{c}\text { Monthly capital and } \\
\text { interest amount (R) }\end{array}$ & $\begin{array}{c}\text { Monthly contribution to } \\
\text { initiation payment (R) }\end{array}$ & $\begin{array}{c}\text { Monthly service } \\
\text { fee (R) }\end{array}$ & $\begin{array}{c}\text { Monthly financing } \\
\text { cost (R) }\end{array}$ \\
\hline 1000.00 & -197.00 & -25.00 & -50.00 & -272.00 \\
\hline 2000.00 & -394.00 & -42.00 & -50.00 & -486.00 \\
\hline 3000.00 & -591.00 & -58.00 & -50.00 & -699.00 \\
\hline 4000.00 & -788.00 & -75.00 & -50.00 & -913.00 \\
\hline 5000.00 & -985.00 & -92.00 & -50.00 & -1127.00 \\
\hline 6000.00 & -1182.00 & -108.00 & -50.00 & -1340.00 \\
\hline 7000.00 & -1379.00 & -125.00 & -50.00 & -1554.00 \\
\hline 8000.00 & -1576.00 & -142.00 & -50.00 & -1768.00 \\
\hline 9000.00 & -1773.00 & -158.00 & -50.00 & -1981.00 \\
\hline 10000.00 & -1970.00 & -167.00 & -50.00 & -2187.00 \\
\hline
\end{tabular}

\subsection{Profitability}

The mean profit made by the informal traders was R4 401 with a standard deviation of R6 574, a mode of R2 000 (when rounded up to the nearest R1 000) a minimum of R2 276 and a maximum of R37 280. Mean operating profit margin was 40 per cent, with a standard deviation of 23 per cent, a minimum of minus 27 per cent and a maximum of 103 per cent. Tables 8 and 9 present statistics summarising profitability of the informal traders. 


\section{Table 8}

Analysis of monthly operating profit

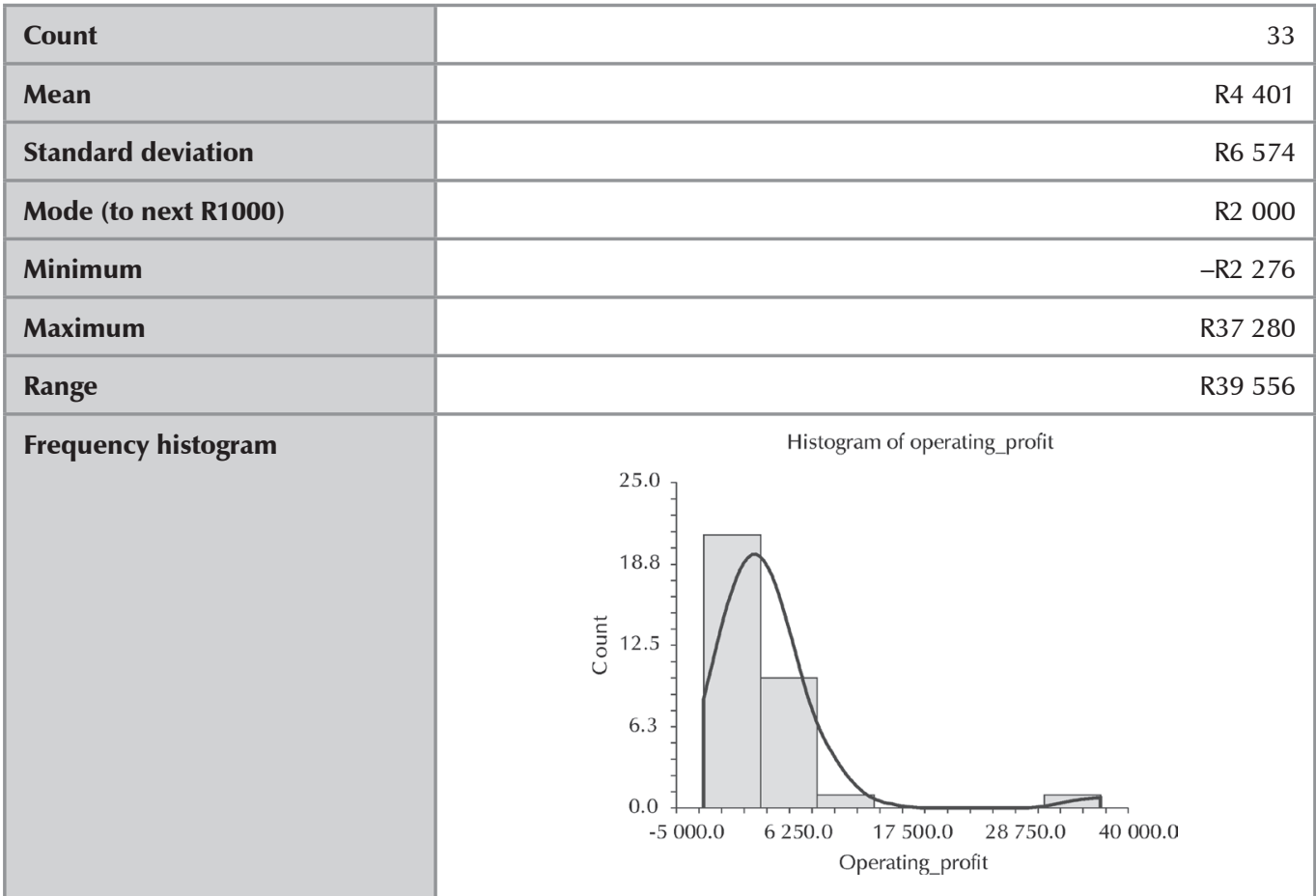

\section{Table 9}

Analysis of operating profit margins

\begin{tabular}{|l|r|r|}
\hline Count & & 33 \\
\hline Mean & & $40 \%$ \\
\hline Standard deviation & $23 \%$ \\
\hline Minimum & & $-27 \%$ \\
\hline Maximum & & $103 \%$ \\
\hline Range & & \\
\hline
\end{tabular}




\subsection{Profitability vs financing costs}

Operating profits were compared to finance costs in order to assess whether the informal traders could actually afford the cost of a loan from a formal institution. However, because the operating profits also covered the informal traders' salaries it was estimated that only 25 per cent of the informal traders' salaries would be available for the payment of finance costs. Table 10 compares the finance costs with the operating profits of the traders.

\section{Table 10}

Finance costs versus operating profits

\begin{tabular}{|c|c|c|c|}
\hline $\begin{array}{c}\text { Loan } \\
\text { amount }\end{array}$ & $\begin{array}{c}\text { Maximum monthly } \\
\text { financing cost }\end{array}$ & $\begin{array}{c}\text { Number of traders } \\
\text { whose operating profit } \\
\text { exceeded maximum } \\
\text { monthly financing cost }\end{array}$ & $\begin{array}{c}\text { Percentage of traders } \\
\text { whose operating profit } \\
\text { exceeded maximum } \\
\text { monthly financing cost }\end{array}$ \\
\hline 1000.00 & 272 & 29 & $88 \%$ \\
\hline 2000.00 & 486 & 20 & $61 \%$ \\
\hline 3000.00 & 699 & 14 & $42 \%$ \\
\hline 4000.00 & 913 & 12 & $36 \%$ \\
\hline 5000.00 & 1340 & 11 & $24 \%$ \\
\hline 6000.00 & 1554 & 8 & $21 \%$ \\
\hline 7000.00 & 1768 & 7 & $18 \%$ \\
\hline 8000.00 & 1981 & 6 & $9 \%$ \\
\hline 9000.00 & 2187 & 2 & $6 \%$ \\
\hline 10000.00 & & 3 & 6 \\
\hline
\end{tabular}

Table 10 above suggests that most of the informal traders generate sufficient operating profits to finance at least part of their capital requirements through the use of formal sector personal debt financing.

\subsection{Formal sector debt financing attractiveness}

The results of this aspect of the research are presented in table 11 below.

Table 11

Summary of responses to the formal sector debt financing attractiveness questionnaire

\begin{tabular}{|l|c|c|}
\hline \multicolumn{1}{|c|}{ Question } & \multicolumn{2}{|c|}{ Response } \\
\hline & Yes & 0 \\
\hline $\begin{array}{l}\text { Would you use formal sector debt financing to meet your business' capital } \\
\text { requirements if it was offered to you? }\end{array}$ & 30 & 30 \\
\hline $\begin{array}{l}\text { Would you prefer using a different form of debt financing, even if formal sector } \\
\text { debt financing was available? }\end{array}$ & 0 & 27 \\
\hline Have you previously used formal sector debt financing? & 3 & 0 \\
\hline $\begin{array}{l}\text { If no, is the primary reason why you have never used formal sector debt } \\
\text { financing before a result of the fact that you did not think that you would qualify? }\end{array}$ & 27 & 0 \\
\hline
\end{tabular}




\begin{tabular}{|l|r|r|}
\hline Do you, or have you previously had a bank account? & 14 & 16 \\
\hline Do you satisfy the following qualification requirements: & 0 & 30 \\
Formally employed? & 13 & 17 \\
Bank account holder? & 15 & 15 \\
SA ID document? & 0 & 30 \\
Payslip? & 4 & 30 \\
3 month bank statement showing income? & 29 & 26 \\
Good credit history? & 0 \\
$21-65$ years old? & 29 \\
\hline
\end{tabular}

All 30 respondents answered positively when asked whether they would consider using formal sector debt financing to meet their businesses' capital requirements. However, few of the traders fulfilled the necessary requirements to apply for formal debt.

\section{5}

\section{Discussion}

\subsection{Capital requirements}

This research revealed that the capital requirements of informal traders were extremely varied with a standard deviation of R4 611 and a range of R29 955.The variation in capital requirements could not be accounted for by the type of business whose capital requirements were very similar (category $1=\mathrm{R} 3551$, category $2=$ R3 710 and category $3=$ R3 998). Therefore, it would appear that the large difference in the capital requirements of different traders was attributable to factors other than the type of products/services sold.

This study also revealed that a substantial (estimated at above 80 per cent) portion of most of the informal businesses' capital requirements related to the purchase of 'stock'. The data obtained from this study were therefore, not directly compatible with those reported by the Department of Trade and Industry (2004), Skinner (2005) and African Response (2006) whose focus was on start-up capital. This observation has a number of implications.

The capital requirements of informal market traders should be short-term in nature. This would reduce the risk associated with long term loans. However it could be argued that the movable nature of 'stock' negated the use of it as collateral and, therefore, increased the risk associated with such a loan. Trade credit would then become a viable option to fund the capital requirements of informal traders.

Most of the traders interviewed had a desire to grow their business beyond what they could achieve through sales alone and required further funding for growth. There were examples of this type of growth amongst the Natalspruit population. One trader, who sold clothes and shoes, grew his business from an operating profit of only a few hundred Rand to R11 955 in only a few years. Originally, the business had no fixed abode but by the time of its research operated from a stall with a stock valued at about R10 000 . Another trader used the money received from filling in surveys for this research project to purchase new stock items (an assortment of scarves and berets), thus growing her business.

The finding that most informal market traders surveyed in Natalspruit would like to expand their business was supported by the data collected in the Wits Business School and Progressus Social Research (2006). The respondents interviewed were questioned on whether they thought that their business was too small, about the right size or too big. The majority (68 per cent) of respondents thought that their business was too small, while only 1 per cent of respondents thought that their business was too big. These findings were also supported by the FinScope Small Business Survey Report Gauteng 2006 (African Response, 2006) which reported that 49 per cent of small businesses planned to expand in the future.

However, the aspiration for expansion was not necessarily translated into action. In the Wits 
Business School and Progressus Social Research (2006) survey, 24 per cent of respondents reported that their business had grown since establishment as opposed to 39 per cent who reported that their business had shrunk since establishment.

\subsection{Formal sector debt financing}

\subsubsection{Minimum loan amounts}

These research findings were in a similar magnitude to those reported by Bay Research and Consultancy Services (2005). The minimum amounts that formal sector institutions were prepared to lend differed considerably and ranged between R50 and R4 000. Unsurprisingly the larger institutions were prepared to lend only larger amounts.

Of the 99 informal market traders interviewed, only one had a capital requirement (R45) less than the smallest amount (R50) than any of the 30 formal sector financial institutions were prepared to lend. Only 17 per cent of the informal market traders had stated capital requirements less than the average minimum loan amount of R875. The average stated capital requirements of the 99 traders interviewed was R3 735 which was significantly larger than R875. Therefore, the answer to the question of whether the capital requirements of informal market traders are large enough to justify the use of formal sector debt financing is 'Yes'.

\subsubsection{Finance costs}

This research supports the findings of Schoombee (2004) that the interest rates for micro-loans were generally exorbitant with a mean of 24 per cent per month for the 30 financial institutions. The results for overall finances costs (interest + charges) calculated in this research varied between 21 per cent and 27 per cent per month. Therefore, those people who were least able to afford it were being charged the highest rates. The situation has improved somewhat with the interest rates legislated by the National Credit Act (Republic of South Africa, 2005).

\subsection{Profitability and financial diaries project}

Previous research by African Response (2006), Skinner (2005), Lathapersad-Pillay (2004), and Ligthelm and Van Wyk (2004) all suggested that most street traders did generate profits albeit in a wide range. These research projects were, however, hampered because informal traders do not generally keep accurate financial records.

The data generated by this research using the more reliable methodology of financial diaries suggest that the selected informal market traders in Natalspruit were even more profitable than was suggested by the above literature, with a mean profitability of R4 401 per month and a mean operating margin of 40 per cent. However, this study also did not subtract the business owner's salary from the profit which may have inflated the figures relative to the other research. It is unclear whether previous studies subtracted the owner's salary from the profitability or not.

This study, however, showed (Table 10) that if it was assumed that the traders had at least 25 per cent of their profit remaining after the owners had subtracted their salaries they would be able to afford at least some of the finance costs of a loan to cover their capital requirements.

The profitability of the selected traders is interesting in light of the extent of the competition evident in Natalspruit. One trader who was engaged in applying hair extensions generated an above average operating profit margin of 70 per cent. This was despite the over 20 other businesses in close proximity offering the same service. One concern is that the influx of competing shopping malls in the townships may negatively affect the profitability of the informal traders. For example, adjacent to Natalspruit market the Letsoho Shopping mall was about to expand. However, when questioned, the informal traders were of the opinion that the expansion of the Letsoho Shopping Centre would be good for business because it would attract more potential customers into the trading area. 


\subsection{Formal sector debt financing attractiveness}

In this research all 30 respondents answered positively when asked whether they would consider using formal sector debt financing to meet their business's capital requirements. However the answer does not paint the full picture. The answer was a definite 'Yes' and reflects what the researchers consider to be a genuine desire to use formal sector debt financing. However, the results of the question posed should not be misinterpreted. The results do not suggest that all the interviewed traders would access formal sector debt financing. The results only suggest that if the trader required additional capital financing, he/she would access this financing if offered to him/her. The definition of the term 'offered' is also relevant. Although all traders indicated that they would use formal sector debt financing if they needed it and it was offered to them, it was also implied in their responses that they would only do so if the effort required to do so was in proportion to the expected benefit.

Informal market traders typically have three options available to them in obtaining financing for their business; namely, self-financing, financing from friends and family and debt financing. Debt financing is usually considered to be the least popular of the three available options. Therefore, the results of the question posed to the 30 interviewed traders regarding the relative attractiveness of formal sector debt financing were surprising. The results of this research suggest that formal sector debt financing is under-utilised not because it is the least popular of the available options, but rather because it is the least accessible of the available options. The two concepts are interrelated, but nonetheless different (and this distinction is important). As table 11 reveals, none of the 30 traders interviewed would have fully satisfied the requirements for financing from a formal institution.

Even the question of whether they were in possession of an SA ID document (and therefore a South African Citizen ${ }^{6}$ ) was a sensitive topic. Natalspruit is home to a large number of foreign informal market traders who feel that they are discriminated against as a result of their nationality-hence the sensitivity. This discrimination has previously been reported, including in a study conducted by Hunter and Skinner (2003). Of the 171 foreign street traders (working in inner city Durban) interviewed for that study, 22 per cent stated that they were harassed by the police, and 12 per cent stated they encountered problems with South Africans. On a different, but related note, is the difficulty of effectively functioning without an ID document. The South African Department of Home Affairs states the purpose of the ID document as follows: '... which enable holders to identify themselves for general purposes and day-to-day activities in society. Identity documents form an important part of each citizen's daily activities since all transactions, whether private or public, require positive identification' (Department of Home Affairs, 2006). It is clear from this statement how important the ID document is.

The general inaccessibility of formal sector debt financing is illustrated by the fact that only four of the interviewed informal market traders had ever made use of formal sector debt financing for business purposes. Three traders had jointly applied for and received a loan of R10 500 (R3 500 each) from a micro finance institution. The loan was used to purchase more stock (second-hand clothes) and required a repayment of R380 per month, for 12 months (from each of the recipients). The fourth trader had made use of a loan from Standard Bank about seven years ago. This almost non-existent historic use of formal sector debt financing by informal market traders can only make it more difficult for them to obtain finance in the future, as a credit record is one of the criteria used by most banks in assessing credit applications.

\section{6}

\section{Conclusions and recommendations}

Having established the capital requirements of informal market traders and comparing these to the minimum loan amounts offered by formal sector debt financing institutions this research can conclude that the capital requirements of informal market traders are large enough to justify 
the use of formal sector debt financing. Statistics revealed that the average capital requirement of informal market traders of R3 735 was considerably more than the average minimum amount of R875 that financial institutions were prepared to loan.

Further, market traders do generate sufficient operating profits to pay for the financing costs associated with the use of formal sector debt financing. The monthly operating profits generated by the informal market were determined and compared with the monthly financing costs associated with formal sector loans. It was determined that that 88 per cent of informal market traders generate sufficient operating profits to pay for the financing costs associated with a loan of R1 000 .

Finally, the research determined whether market traders were willing to utilise formal sector debt financing. The informal market traders were prepared to use formal sector debt financing, but they perceived such financing as being inaccessible to them.

However, two important caveats to these results are noted. Firstly, formal sector debt financing should only be provided to those informal market traders with proven ability and appetite. Based on the extensive coaching required in the financial diaries project, it can be concluded that many informal traders do not possess the necessary ability and/or appetite to effectively use formal sector debt financing if provided. The provision of formal sector debt financing to these traders would disadvantage them and should thus be discouraged. Formal sector debt financing does not represent a panacea for funding the capital requirements of all informal market traders, and alternative funding options require investigation.

Secondly, formal sector debt financing should only be provided to those informal market traders who are prepared to inject more formality into their businesses. Formalisation has both its advantages and disadvantages for informal market traders. Each informal market trader needs to weigh these and make a decision that is appropriate for his/her business. However, formal sector debt financing by its nature requires a degree of formality and only those informal market traders prepared to do so should expect the opportunity to access this form of financing.

There are, following from these results, a number of recommendations that may be made with respect to informal market development. In order to formalise their businesses, traders require improved financial literacy, which includes record keeping and familiarity with the banking system. Therefore, in addition to training, the use of basic banking products should also be encouraged. It is also important that those informal market traders who are provided access to formal sector debt financing are encouraged to utilise this financing appropriately in order to improve the absolute operating profits generated and/or improve the operating margins realised. Examples of this would include using the funds to buy more stock, buying (and selling) higher value products, employing more staff (in service businesses) and securing better supply sources.

In conclusion, this research sought to determine whether debt financing would be appropriate in funding the capital requirements of informal market traders. The results show that, with certain caveats and the appropriate training, informal market traders may be able to make use of formal sector debt financing to fund their capital requirements. Given the potential contribution of informal trading to the South African economy, and the precepts of the Financial Sector Charter (SA Treasury, 2003), it would be appropriate for both development authorities and financial institutions to pursue the appropriate provision of debt to informal market traders.

\section{Endnotes}

1 2
According to the official definition of unemployment The authors gratefully acknowledge the support of the Ekhuruleni Metropolitan Council for this research.

3 The term 'hawker' closely corresponded with the definition of the informal market

4 According to this survey informal/street/market/ stall traders generated an average annual turnover of R18 620 (which equates to an average monthly turnover of R1 552). Using a net profit margin of 25 per cent, this category of small business was generating an average monthly net profit of R388. 
5 The MFRC was the forerunner to the NCR (and is still the custodian for much of the data.

6 A South African ID document can also be issued to a person to whom permanent residence has been granted, a person who has been exempt in terms of the Aliens Control Act, 1991, or to a refugee.

\section{References}

AFRICAN RESPONSE. 2006. FinScope small business survey report Gauteng 2006, for Gauteng Enterprise Propeller and FinMark Trust, Johannesburg. BAY RESEARCH AND CONSULTANCY SERVICES. 2005. The pro-poor microfinance sector in South Africa, for FinMark Trust, Cape Town. CICHELLO, P. 2005. Hindrances to self-employment activity: evidence from the 2000 Khayelitsha/Mitchell's Plain survey, Cape Town: Centre for Social Science Research University of Cape Town.

DEPARTMENT OF HOME AFFAIRS. 2006.

Directorate: ID documents, last accessed 5 June, 2007, from http://www.home-affairs.gov.za.

DEPARTMENT OF TRADE AND INDUSTRY. 2004. Annual review of small business in South Africa 2004, Department of Trade and Industry, Pretoria. GITMAN, L. 2000. Principles of managerial finance ( $9^{\text {th }}$ ed.) Reading: Addison Wesley Publishing Company. GLACKIN, C. 2002. What does it take to borrow? a framework for analysis, Journal of Microfinance, 4(1): 115-135.

HUNTER, N. AND SKINNER, C. 2003. Foreign street traders working in inner city Durban: local government policy challenges, Urban Forum, 14(4): 301-319.

INTERNATIONAL LABOUR ORGANISATION. 2003. International Labour Organisation booklet on street traders, International Labour Organisation, Geneva.

KAUFFMANN, C. 2006. Financing small and medium enterprises in Africa, African Technology Development Forum Journal, 3(2): 3-6.

KINGDON, G. \& KNIGHT, J. 2005. Unemployment in South Africa, 1995-2003: causes, problems and policies, Johannesburg: National Institute for Economic Policy in South Africa.

LALTHAPERSAD-PILLAY, P. 2004. A socioeconomic analysis of African female street traders in the Johannesburg Cbd, South African Journal of Economic and Management Sciences, 7(1): 22-44. LIGTHELM, A. 2005. Informal markets in Tshwane: entrepreneurial incubators or survivalist reservoirs,
Pretoria: Bureau of Market Research University of South Africa.

LIGTHELM, A. 2006. An evaluation of the role and potential of the informal economy for employment creation in South Africa, South African Journal of Labour Relations, 30(1): 30-50.

LIGTHELM, A. \& VAN WYK, A. 2004. Informal trading in Tshwane: regulatory, spatial and economic framework, Bureau of Market Research University of South Africa, Pretoria.

MICRO FINANCE REGULATORY COUNCIL. 2006. Different types of lenders, last accessed 21

November, 2006, from www.mfrc.co.za.

REPUBLIC OF SOUTH AFRICA. 2005. National

Credit Act No.34 of 2005, Government Gazette number 28619, Pretoria: Government Printer.

SA TREASURY. 2003. Financial sector charter, 17 October, last accessed 10 November 2009. http://www. treasury.gov.za/comm_media/press/2003/2003101701. pdf.

SCHOOMBEE, A. 1998. Commercial banking services for micro-entrepreneurs in South Africa, South African Journal of Economics, 66(3): 338-362.

SCHOOMBEE, A. 1999. Linkage banking for microenterprises in South Africa, South African Journal of Economics, 67(3): 419-455.

SCHOOMBEE, A. 2004. South African banks and the underbanked: progress and prospects, South African Journal of Economics, 72(3): 581-603.

SCHREINER, M. 2001. Seven aspects of loan size, Journal of Microfinance, 3(2): 27-47.

SKINNER, C. 2005. Constraints to growth and employment in Durban: evidence from the informal economy, Durban: School of Development Studies University of KwaZulu-Natal.

STASCHEN, S. 1999. Regulation and supervision of microfinance institutions in South Africa, Eschborn: Deutsche Gesellschaft für Technische Zusammenarbeit.

STATISTICS SOUTH AFRICA. 2008. Labour force survey, last accessed 04 November 2009, from http:// www.statssa.gov.za/publications/P02111/P021112008. pdf.

STATISTICS SOUTH AFRICA. 2009. Key indicators, last accessed 04 November 2009, from http://www. statssa.gov.za/keyindicators/keyindicators.asp. UKUKHULA BUSINESS SOLUTIONS. 2002. Draft informal beach trading policy and management framework, City of Cape Town.

WITS BUSINESS SCHOOL AND PROGRESSUS SOCIAL RESEARCH. 2006. Survey of Natalspruit informal market traders, 27 June-1 July, Johannesburg. 